\title{
ALIRAN- ALIRAN FILSAFAT DALAM MATEMATIKA
}

\author{
Agung Prabowo \\ Fakultas Sains dan Teknik, Universitas Jenderal Soedirman \\ Purwokerto, Indonesia \\ Email : agung_nghp@yahoo.com
}

\begin{abstract}
Mathematical philosophy doesn't add a number of new mathematical theorems or teories, so mathematical phylosophy is not mathematics. Mathematical phylosophy is a reflection on mathematics. After having studied for a long time, one need to reflect the result of the study by reflecting it to mathematical phylosophy. This article discusses the mathematical phylosophy streams and their role and function, and describes formalism mathematical phylosophy specially.
\end{abstract}

Keywords: mathematical philosophy, formalism

\section{Pendahuluan}

Pada masa sebelum adanya filsafat matematika, untuk mengatasi terjadinya kontradiksi salah satu caranya adalah dengan melenyapkan subyek penyebab terjadinya kontradiksi tersebut. Agar filsafat Pythagoras all is number tetap suci dan terjaga, maka Hippasus, sebagai penemu $\sqrt{2}$ yang merupakan bilangan irasional dan potensial untuk merusak filsafat Pythagoras, perlu untuk dibiarkan menjemput maut di tengah laut. Kontradiksi yang dimuculkan Hippasus dalam sistem bilangan rasioal yang dibangun Pythagoras, saat ini tidak perlu diselesaikan secara berdarah. Harus dikedepankan penyelesaian yang beradab. Oleh karena itu, perlu adanya sebuah sistem, dan itu adalah filsafat matematika, supaya pengetahuan matematis menempati posisi yang secara sistematis mempunyai kebenaran yang terjaga dan terbebas dari berbagai kontradiksi.

Filsafat matematika bersifat pragmatik-eklektik, artinya perbedaan aliran filsafat tidak harus menimbulkan perang senjata seperti yang terjadi pada perbedaan madzhab politik, tetapi cukup diselesaikan dengan perang pena, polemik dan berwacana. Dengan bercermin pada filsafat matematika, pekerja matematika (tidak harus matematikawan) dapat meyakini apakah selama ini dan saat ini telah bekerja pada arah yang benar. 
Artikel ini ditulis dengan tujuan berbagi informasi mengenai topik lama yang kurang populer dalam matematika, serta tidak terlalu dikembangkan di Indonesia. Artikel ini disusun untuk menjawab permasalahan seputar upaya-upaya apa yang perlu dilakukan guna mengatasi terjadinya krisis, kontradiksi dan paradok dalam matematika serta menjawab pertanyaan landasan filsafat matematika mana yang saat ini banyak digunakan untuk membelajarkan dan mengembangkan matematika. Berkaitan dengan permasalahan pertama dipaparkan aliran filsafat matematika platonisme, logisisme, intuisionisme dan falibilisme. Berkaitan dengan permasalahan kedua, secara khusus artikel ini fokus pada pembahasan mengenai filsafat matematika formalisme.

Artikel ini dapat dipandang sebagai suatu kontribusi kecil dalam khasanah matematika dan sebagai artikel yang sangat awal, isi artikel sekedar mengingatkan dan menyegarkan kepada pembaca lama tetapi juga memperkenalkan aliran-aliran filsafat dalam matematika kepada pembaca baru, bahwa yang demikian itu memang ada. Itulah tujuan penulisannya. Pembaca dapat memetik berbagai pengetahuan berharga dari tulisan ini. Pada bagian akhir diberikan paparan naratif ketidaktepatan filsafat formalisme sebagai fondasi untuk membangun matematika.

\section{Pembahasan}

Akar kata filsafat secara etimologi dapat dilacak pada bahasa Yunani phillein yang berarti cinta dan sophia yang berarti kebijaksanaan. Jadi, filsafat berarti cinta pada kebijaksanaan. Dengan berfilsafat akan diperoleh hakikat segala pengetahuan atau pengetahuan terdalam. Ada empat hal yang mendorong manusia berfilsafat yaitu keraguan, ketakjuban, ketidakpuasan, dan hasrat bertanya (Sukardjono, 2000). Untuk mencapai pengetahuan terdalam maka berfilsafat dilakukan dengan berpikir radikal (sampai ke akar-akarnya), mencari azas/esensi dari setiap realita, memburu kebenaran, mencari kejelasan seluruh realita, serta berpikir rasional, logis, dan sistematis. 
Menurut P. Hilton (Gunawan, 2007) matematika lahir dan berkembang karena adanya keinginan manusia untuk mensistematisasikan pengalaman hidupnya, menatanya dan membuatnya mudah dimengerti, supaya dapat meramalkan dan bila memungkinkan mengendalikan peristiwa yang akan terjadi pada masa depan. Perkembangan matematika bersifat evolutif, akumulatif dan dikembangkan serta disumbang oleh berbagai bangsa di seluruh dunia. Seringkali, perkembangan matematika pada suatu bangsa akan menemui keruntuhan, tetapi sebelum benar-benar runtuh, telah ada bangsa lain yang siap untuk meneruskan perkembangannya. Hal ini menunjukkan bahwa perkembangan matematika terjadi secara kontinu dan tersusun dari kepingan-kepingan yang dihimpun oleh banyak bangsa dan kebudayaan selama berabad-abad.

Esensi dari filsafat matematika adalah sejumlah usaha untuk melakukan rekonstruksi (penyusunan kembali atau penulisan ulang) terhadap sejumlah pengetahuan matematika yang tercerai-berai selama bertahun-tahun yang diberikan dalam aturan atau urutan tertentu. Jadi filsafat adalah fungsi dari waktu, dan fisafat dapat menjadi ketinggalan jaman atau harus berbenah dan berubah sejalan dengan bertambahnya pengalaman dan pengetahuan baru.

Menurut Korner (Ernest, 1991), filsafat matematika tidaklah menambahkan sejumlah teorema dan teori matematika baru, sehingga filsafat matematika bukanlah matematika. Filsafat matematika adalah refleksi mengenai matematika, yang menimbulkan munculnya pertanyaan dan jawaban tertentu. Menurut I. Stewart (Gunawan, 2007) bila naluri engineers adalah merekayasa alam dan naluri scientists adalah memahami alam dan mencari tahu apa yang sesungguhnya terjadi, maka naluri matematikawan adalah menstrukturkan proses pemahaman tersebut dengan mencari kesamaan pola di antara berbagai fenomena.

Pengetahuan matematika adalah himpunan kebenaran yang disajikan dalam bentuk proposisi, lengkap dengan pembuktianya, sehingga fungsi dari filsafat matematika adalah menetapkan kepastian pengetahuan matematika. Secara tradisional, filsafat matematika mempertanyakan dasar-dasar untuk memperoleh pengetahuan matematis yang pasti tersebut (Sukardjono, 2000). 
Dengan kata lain, perlu adanya sebuah sistem, dan itu adalah filsafat matematika, supaya pengetahuan matematis menempati posisi yang secara sistematis mempunyai kebenaran yang terjaga

Peranan filsafat secara umum adalah sebagai pendobrak mitos dan kelaziman, sebagai pembebas dan menjadi pembimbing berpikir secara koheren dan integral (utuh menyeluruh) (Suriasumantri, 2005; Woods, 2006). Sementara itu, filsafat matematika berperan menyediakan landasan/fondasi pengetahuan matematis yang sistematis dan yang secara absolut dapat melindungi landasan tersebut dari berbagai macam kontradiksi dan paradok dalam kaitannya dengan kebenaran matematis (Sukardjono, 2000). Peran yang seperti ini berkaitan dengan dasar-dasar landasan matematika yang telah dikembangkan oleh aliran absolutisme yang menjadi pusat dari seluruh filsafat matematika, saat ini.

Agar matematika menjadi satu, utuh dan terpadu maka keberadaan filsafat matematika menjadi perlu dan mutlak harus ada. Harapan besar dibebankan kepada para filosof dan matematikawan untuk menjadikan filsafat matematika sebagai penyusun, penghimpun, dan penertib ilmu matematika yang telah terpecah menjadi kepingan-kepingan selama berabad-abad, akibat banyaknya kontradiksi yang mewarnai perkembangan matematika dan meminta untuk diselesaikan.

\subsection{Latar Belakang Perlunya Filsafat Matematika}

\subsubsection{Kontradiksi}

Pengetahuan matematika diturunkan dengan deduksi logis, sehingga matematika diklaim sebagai ilmu yang sempurna dan suci tak ternoda kesalahan. Namun, sesaat setelah itu bermunculan kontradiksi dalam matematika, sekumpulan obyek matematika yang aneh dan liar, antara lain: tidak mungkin dapat selalu menyatakan panjang diagonal sebuah persegi panjang dalam bentuk bilangan kuadrat, adanya bilangan irasional seperti $\sqrt{2}$, adanya bilangan transfinit dan bilangan transendental (pi) yang misterius, dan bilangan imajiner $(i=\sqrt{-1})$. 
Dalam matematika hari ini banyak ditemukan sekawanan obyek-obyek matematika yang aneh dan liar -yang belum dapat dijinakkan- meskipun berbagai upaya domestifikasi telah dilakukan. Contoh terbaru adalah penemuan bilangan $Q$ oleh Paul Dirac dalam mekanika kuantum yang melanggar aturan matematika $a \times b=b \times a$ (Woods, 2006). Kawanan tersebut adalah sejenis kontradiksi dalam matematika, yang jika ditolak akan menyebabkan matematika menjadi mandul. Penerimaan setengah hati yang disertai dengan upaya domestifikasi terhadap sekawanan yang aneh dan liar tersebut justru terbukti memberikan manfaat yang sangat besar bagi matematika.

\subsubsection{Paradok}

Matematikawan adalah mahluk yang cerdik dan tidak bersedia menerima jika (re)konstruksinya gagal. Memilih menyembunyikan kontradiksi-kontradiksi tersebut dengan sebuah penghalusan atau eufemisne, bahwa yang terjadi bukanlah kontradiksi tetapi paradok, merupakan pilihan cerdas yang dapat dilakukan. Semacam anomali. Dengan kecerdikan yang demikian matematika tetap berjaya, terbebas dari segala kesalahan dan tentunya terbebas dari kontradiksi.

Paradok antara lain muncul dari dialog Socrates dengan Plato berikut ini (Sembiring, 2010). Socrates: "Apa yang berikut ini akan dikatakan oleh Plato adalah salah." Plato mengatakan: "Yang barusan dikatakan Socrates benar." Contoh yang cukup populer adalah paradok Zeno $( \pm 450 \mathrm{SM})$ yang menemukan adanya kesulitan mengenai ide kuantitas kecil tak berhingga sebagai penyusun besaran kontinu. Zeno mencoba membuktikan bahwa pergerakan ke arah kecil tak berhingga adalah khayalan. Paradok Zeno mengenai 'Achiles si Gesit' begitu terkenal dan memukau ke arah penelusuran konsep ketakberhinggan. Kata Zeno, yang lebih lambat tidak dapat disalip oleh yang lebih cepat, sehingga Achiles si Gesit tidak akan mampu menyalip atau mendahului kuya.

Paradok ini tidaklah menyatakan bahwa dalam praktek lomba lari yang sebenarnya Achiles tidak dapat menyalip kura-kura, tetapi memberi gambaran bagaimana terbatasnya pemikiran dalam logika formal matematika. 
Upaya menyelesaikan berbagai paradok menyebabkan terpecahnya matematikawan ke dalam beberapa arus pikiran atau filsafat. Lahirlah faksi-faksi dan aliran-aliran dalam filsafat matematika, yang saling berbeda dan saling tidak mau menerima satu sama lain.

Menyembunyikan kontradiksi dalam paradok tidak selalu membuat pekerja matematika dapat tidur dengan nyenyak. Matematikawan juga adalah mahluk yang tidak dapat menipu dirinya sendiri. Kontradiksi tetaplah kontradiksi, bersifat mengurangi nilai keindahan matematika, meskipun diperhalus terusmenerus. Secara eksternal matematikawan menyatakan matematika bebas dari kontradiksi, tetapi diam-diam mereka melanjutkan pekerjaan menyelesaikan berbagai kontradiksi tersebut, dan memastikan bahwa penyelesaian yang dilakukannya tidak akan menimbulkan kontradiksi baru, sehingga konsistensi matematika tetap tegak berdiri, bendera matematika berkibar di tiang tertinggi dengan lantang dan gagah berani menatap langit biru, tidak akan pernah berkibar setengah tiang dan malu-malu.

Para matematikawan mencoba menyelesaikan masalah-masalah tersebut, membuang kontradiksi dan mengembangkan sistem matematika baru yang kebal salah. Mereka membuat rekonstruksi baru atas struktur logika matematika, dan mulai meninggalkan kepercayaan pada disain alam semesta yang matematis. Meskipun merupakan suatu kebenaran bahwa matematika telah tersedia di alam semesta dan orang tinggal menemukannya, keyakinan tersebut harus ditinggalkan dan beralih pada matematika yang merupakan hasil konstruksi pikiran bebas manusia yang kebenarannya tidak perlu harus sesuai dengan apa yang terjadi di alam semesta, cukup kebenaran karena kesepakatan. Tetapi, lagi-lagi muncul kontradiksi yang mencemari logika matematika dalam rekonstruksi baru tersebut, misalnya paradok Russel dan paradok Burali-Forti. 


\subsubsection{Krisis Matematika}

Munculnya filsafat matematika disebabkan oleh adanya kontradiksi, paradok dan terjadinya krisis dalam matematika. Setidaknya, pernah tercatat tiga kali krisis dalam metamatika: (1) Abad ke-5 SM, tidak semua besaran geometri yang sejenis, tidak memiliki satuan ukuran yang sama (Sukardjono, 2000). Krisis ini menyebabkan teori proporsi Pythagoras harus dicoret dari matematika. Krisis yang disadari sangat terlambat, lima abad kemudian baru dapat diatasi oleh Eudoxus dengan karyanya yang membahas bilangan irasional, (2) Abad ke-17, Newton dan Leibniz menemukan kalkulus yang didasarkan pada konsep infinitesimal, tetapi tidak dapat dijelaskan dengan baik. Namun, hasil-hasil penerapan kalkulus justru digunakan untuk menjelaskan konsep infinitesimal, suatu penjelasan yang tidak seharusnya dilakukan. Baru awal abad ke-19, Cauchy memperbaiki konsep infinitesimal sebagai landasan kalkulus dengan konsep limit. Weierstrass membuat konsep limit menjadi lebih kokoh, (3) Georg Cantor menemukan teori himpunan yang digunakan secara luas pada cabang-cabang matematika dan menjadi landasan matematika. Namun demikian, penemuan ini juga menghasilkan paradok misalnya paradok Burali-Forti dan paradok Russel.

\subsection{Aliran-Aliran dalam Filsafat Matematika}

Bagaimana matematikawan mengatasi ketiga krisis di atas, adalah dengan melihat dan pergi ke filsafat matematika, sehingga di dalam matematika dikenal adanya berbagai aliran (madzhab) filsafat yang dianut dan dikembangkan oleh tokohnya masing-masing.

Filsafat matematika dikembangkan melalui isu-isu eksternal seperti sejarah, asal-usul, dan praktek matematika dengan isu-isu internal seperti epistemologi dan ontologi. Metode yang digunakan untuk melakukan klasifikasi aliran-aliran dalam filsafat matematika salah satunya menggunakan kriteria kecukupan filsafat matematika (Ernest, 1991) yaitu: (1) pengetahuan matematika: sifat, justifikasi, dan asal-usul pengetahuan, (2) obyek matematika: ruang lingkup dan asal-usul obyek matematika, (3) aplikasi matematika: efektifitas matematika dalam mengembangkan sains, teknologi dan aplikasi lainnya, dan (4) praktek matematika: aktifitas matematikawan, dulu dan sekarang. 
Kriteria tersebut saat ini melahirkan beberapa aliran filsafat matematika, yaitu Platonisme, Absolutisme dan Falibilisme. Platonisme lebih menekankan pada tidak adanya landasan-landasan untuk merekonstruksi dan menyelamatkan matematika, sementara itu, absolutisme lebih menekankan pada tidak adanya kesalahan pada matematika, sedangkan falibilisme menekankan pada kemungkinan matematika untuk direvisi terus-menerus.

\subsubsection{Platonisme}

Platonisme menganggap matematika adalah kebenaran mutlak dan pengetahuan matematika merupakan hasil ilham Illahi. (Tuhan adalah salah seorang ahli matematika atau matematikawan). Platonisme memandang obyekobyek matematika adalah real dan eksistensi real obyek dan struktur matematika adalah sebagai eksistensi realitas yang ideal dan bebas dari sifat manusiawi. Kegiatan matematika adalah proses menemukan hubungan-hubungan yang telah ada di alam semesta.

Kurt Godel sebagai salah satu pengusung Platonisme di jaman modern sekarang ini menyatakan bahwa bilangan adalah abstrak (Sukardjono, 2000) sehingga diperlukan adanya eksistensi suatu obyek yang bebas dari pikiran manusia untuk menyatakannya. Oleh karena bilangan adalah independen/bebas dan keberadaannya bersifat obyektif, maka sebarang proposisi $p$ mengenai suatu bilangan dapat salah atau benar, sebab proposisi tersebut dapat secara tepat menggambarkan abstraksi obyek (bilangan) tersebut, atau tidak. Demikian juga, oleh karena total banyaknya bilangan adalah tak hingga, maka akan terdapat inspeksi yang dilakukan oleh Tuhan yang mampu berpikir cepat dan tak terhingga untuk melakukan pemeriksaan setiap bilangan guna melihat bagaimana sebuah pernyataan $p$ tersebut. Setelah selesai dilakukan, Tuhan akan melaporkan apakah $p$ atau bukan $p$.

Platonisme juga berpandangan bahwa manusia (dan Tuhan) dapat mengidentifikasi obyek-obyek abstrak, mengenal ruas garis atau himpunan. Kenyataan bahwa dalam memahami konsep abstrak, seringkali dengan cara menghubungkan obyek-obyek fisik secara bebas dan terbuka, tidak berarti manusia tidak dapat mengidentifikasi obyek-obyek abstrak tersebut. 


\subsubsection{Absolutisme}

Pengetahuan matematika terdiri dari kebenaran yang sudah pasti dan tidak dapat diubah, kebenaran yang bersifat absolut/mutlak, merupakan satu-satunya realitas pengetahuan yang sudah pasti, dan kebenarannya hanya tergantung pada logika dan kebenaran yang terkandung dalam term-term-nya. Kebenaran matematika diturunkan dari definisi-definisi dan tidak dapat dikonfirmasi dengan fakta empiris. Metode deduktif memberikan jaminan untuk melakukan asersi pengetahuan matematika dengan benar. Klaim bahwa matematika (dan logika) adalah pengetahuan yang pasti benar secara mutlak, ditopang oleh pernyataan dasar yang digunakan dalam pembuktian merupakan pernyataan yang benar. Untuk tujuan mengembangkan sebuah sistem matematika berdasarkan kesepakatan, aksioma-aksioma matematika diasumsikan benar. Dengan demikian definisi matematika benar by fiat, dan teorema-teoremanya secara logika diterima sebagai benar. Selain itu, aturan-aturan logika yang digunakan untuk menarik pengetahuan baru adalah benar, menolak segala sesuatu, kecuali bahwa kebenaran diturunkan dari kebenaran pula.

Munculnya aliran absolutisme dalam matematika dipicu oleh adanya perbedaan setidaknya dalam dua hal berikut (Sukardjono, 2000). Pertama, pandangan umum bahwa matematika merupakan resultan antara sistem aksiomatik dan sistem logika. Pandangan ini menyatakan eratnya hubungan antara matematika dengan logika. Sebagian menganggap logika tercakup dalam matematika (aliran formalisme) dan sejalan dengan hal itu, intuisionisme berpendapat logika adalah cabang dari matematika. Sementara yang tidak setuju menyatakan bahwa logika adalah segalanya, sedangkan matematika adalah sebagian kecil dari logika, atau matematika adalah cabang dari logika (aliran logisisme). Kedua, terjadinya krisis landasan metamatika, yang melanda pondasi teori himpunan dan logika formal, membawa matematikawan mencari landasan filsafat untuk merekonstruksi matematika agar diperoleh landasan yang lebih kokoh. Kedua kenyataan ini memunculkan tiga arus utama filsafat matematika yaitu aliran logisisme dipimpin oleh Russel dan Whitehead, aliran intuisionisme dipimpin oleh Brouwer, dan aliran formalisme dipimpin oleh David Hilbert. 


\subsubsection{Logisisme}

Perkembangan logika, sebagai ilmu pengetahuan yang memuat prinsipprinsip dan ide-ide yang mendasari semua ilmu pengetahuan lain, setidaknya dimulai oleh Leibniz tahun 1666. Reduksi konsep-konsep matematika ke dalam konsep logika telah dimulai pada era Dedekind tahun 1888) dan Gottlob Frege antara 1884- 1903). Sementara itu, Peano mengerjakan proyek "melogikakan matematika" dengan menuliskan teorema-teorema matematika ke dalam lambang logika antara tahun 1889-1908. Dedekind, Frege, dan Peano kemudian mendirikan aliran Logisisme yang puncak perkembangannya dicapai oleh Bertrand Arthur William Russel (1872-1970) dan Alfred North Whitehead (1861-1947) melalui karya monumental Russel-Whitehead, Principia Mathematica, sebuah karya dari keindahan logika, yang berusaha mereduksi seluruh matematika ke dalam logika. Melogikakan matematika dengan cara yang lebih smooth telah dilakukan Wittgenstein (1922), Chwistek (1924-25), Ramsey (1926), Langford (1927), Carnap (1931), dan Quine (1940) (Sukardjono, 2000).

Tesis Logisisme adalah matematika sebagai cabang dari logika. Menurut aliran ini, seluruh matematika dari sejak jaman kuno perlu dikonstruksi kembali ke dalam term-term logika dan tentu saja programnya adalah mengubah seluruh matematika ke dalam logika. Semua konsep matematika haruslah dirumuskan dalam term-term logika dan semua teorema matematika harus dikembangkan sebagai teorema logika. Tesis ini muncul sebagai upaya untuk meletakkan pondasi matematika ke tempat yang paling dasar dan paling dalam. Pondasi matematika yang saat ini digunakan dibangun dengan sistem bilangan real, didorong ke sistem bilangan asli, dan akhirnya didorong lagi ke teori himpunan.

Bertrand Russel berhasil memperlihatkan bahwa dua buah klaim aliran logisisme berikut dapat diselesikan dengan logika (Sukardjono, 2000) yaitu (1) seluruh konsep matematika secara mutlak dapat direduksi ke dalam konsep logika, tercakup dalam konsep teori himpunan atau beberapa sistem yang kekuatannya sama, seperti Teori Type dan (2) seluruh kebenaran matematika dapat dibuktikan dari aksioma dan aturan-aturan inferensi dalam logika. 
Tujuan kedua klaim ini adalah jika seluruh matematika dapat diekspresikan ke dalam term-term logika secara murni dan dapat dibuktikan menggunakan prinsip-prinsip logika, maka kepastian pengetahuan matematika dapat direduksi ke dalam logika. Jadi, tugas logisisme adalah menyediakan dasar logika untuk pengetahuan matematika secara pasti dan meyakinkan serta mengukuhkan kembali kemutlakan kepastian dalam matematika.

\subsubsection{Intuisionisme}

Intuisionisme adalah aliran filsafat dalam tradisi Kant bahwa semua pengetahuan manusia diawali oleh intuisi, menghasilkan konsep-konsep, dan diakhiri dengan ide-ide. Setidaknya untuk semua tujuan praktis, segala sesuatu, termasuk matematika, hanya ada dalam pikiran. Aliran Intuisionisme mulai dikembangkan sekitar 1908 oleh matematikawan Belanda L.J.W. Brouwer (18821966), meskipun beberapa ide awal intuisionisme diketahui telah ada, seperti yang dirumuskan Kronecker (1890-an) dan Poincare antara 1902-1906. L.E.J. Brouwer menyatakan bahwa matematika adalah kreasi pikiran manusia. Bilangan ibarat karakter dalam cerita dongeng, hanyalah entitas mental, yang tidak akan pernah ada, kecuali dalam pikiran manusia yang memikirkannya. Jadi, intuisionisme menolak keberadaan obyek-obyek dalam matematika.

Aliran Intuisionisme tidak memandang kebenaran matematis sebagai struktur obyektif seperti pendapat aliran Formalisisme dan Logisisme. Menurut aliran ini, matematika tidak akan dapat seluruhnya dilambangkan, berpikir matematis tidak tergantung pada bahasa tertentu yang digunakan untuk mengungkapkannya. Pengetahuan dari proses matematis haruslah sedemikian sehingga proses itu dapat diperluas hingga tak terbatas.

Tesis aliran Intusionisme adalah matematika harus dibangun semata-mata atas dasar metode konstruktif finit (dalam sejumlah langkah yang hingga) dengan dasar barisan bilangan asli yang diketahui secara intuitif. 
Menurut aliran ini, pada dasar yang paling dalam terletak intuisi primitif, bersekutu dan bekerja sama dengan akal duniawi manusia, yang memungkinkan manusia mengangankan suatu obyek tunggal, kemudian satu lagi, satu lagi dan seterusnya tak berakhir. Dengan cara ini diperoleh barisan tak berakhir, yang dikenal dengan barisan bilangan alam. Dengan menggunakan dasar intuitif bilangan asli ini, sebarang obyek matematika harus dibangun dengan cara konstruktif murni, dengan menggunakan operasi dan langkah-langkah yang banyaknya berhingga.

Bagi kaum Intuisionis, suatu himpunan tak boleh dipikirkan sebagai koleksi yang telah siap jadi, akan tetapi harus dipandang sebagai hukum yang elemen-elemennya dapat atau harus dikonstruksi selangkah demi selangkah. Konsep himpunan seperti ini dapat membebaskan matematika dari kemungkinan terjadinya kontradiksi, seperti munculnya kontradiksi pada pernyataan "himpunan semua himpunan”. Kaum Intuisionis juga menolak pendapat aliran formalisme bahwa hukum excluded midle dan hukum kontradiksi adalah ekuivalen.

Heyting pada tahun 1939 mulai membangun piranti logis intuisionis dengan mengembangkan lambang logika kaum intuisionis. Kaum Intuisionis dengan logika yang dikembangkannya sendiri telah berjaya dengan berhasil menyusun kembali sebagian besar matematika masa kini, termasuk teori kekontinuan dan teori himpunan. Namun demikian, akibat dari tesisnya sendiri terlalu banyak hal menarik dalam matematika yang harus dihilangkan dan dikorbankan. Kekurangan lainnya, matematika intusionis dianggap sebagai kurang kuat dibanding matematika klasik, dan dalam banyak hal jauh lebih rumit untuk berkembang. Kelebihannya, metode intuisionisme diyakini tidak menghasilkan kontradiksi.

\subsubsection{Falibilisme}

Menurut falibilisme, kebenaran matematika dapat menjadi subyek yang begitu sederhana, dan dalam banyak hal dapat dikritisi. Kebenaran matematika bersifat tidak sempurna (falibel), tidak kokoh, dan di masa depan dapat dikoreksi serta direvisi. 
Tesis aliran falibilisme dinyatakan dalam dua pernyataan. Dalam bentuk negatif, aliran falibilisme fokus untuk menolak pandangan absolutisme, dinyatakan sebagai kebenaran matematika bukanlah kebenaran yang mutlak dan kebenarannya tidak mempunyai validasi yang mutlak. Dalam bentuk positif, falibilisme menyatakan bahwa kebenaran matematika adalah tidak kokoh dan setiap saat terbuka untuk direvisi sampai tak hingga kali.

Aliran Falibilisme menyatakan bahwa isi matematika murni pada akhirnya diturunkan dari dunia material. Menurutnya, matematika menangani hubungan kuantitaif dalam dunia nyata, sehingga asumsi kebenaran seperangkat aksioma baru akan nampak terbukti setelah melalui masa-masa panjang pengamatan dan pengalaman atas realitas, bukan berdasarkan pembuktian secara deduktifaksiomatik. Hal ini didukung oleh kemampuan operasi matematika diterapkan pada dunia nyata dan mendapatkan hasil yang bermakna, yang memperlihatkan adanya tarik menarik (afinitas) antara matematika dan dunia nyata, sehingga matematika memiliki kegunaan praktis.

Menurut Lakatos (Ernest, 1991) banyak hasil kerja ahli matematika, ahli logika, dan filosof (seperti hasil kerja dari Russel, Fraenkel, Carnap, Weyl, von Neumann, Bernays, Church, Godel, Quine, Rosser, Curry, Mostowski, dan Kalmar) yang berpandangan bahwa tidak mungkin terdapat kepastian yang lengkap dalam matematika, bahkan mereka cenderung mendukung bahwa pengetahuan matematika mempunyai dan memerlukan landasan empiris, sebagai pintu masuk untuk menolak absolutisme.

Penolakan terhadap absolutisme tidaklah berarti bahwa matematika terbuang dari Taman Eden, tidak mempunyai realitas yang pasti dan kebenaran. Hilangnya kepastian tidak berarti hilangnya pengetahuan, sebab falibilisme menyatakan bahwa pandangan absolutisme hanyalah sebuah idealisasi berlebihan, lebih sebagai sebuah mitos belaka. Bagi aliran falibilisme matematika yang dikembangkan aliran absolutisme adalah dongeng indah yang tidak membumi. 


\subsection{Filsafat Formalisme dalam Matematika}

Untuk mengetahui filsafat matematika dapat dimulai dengan pertanyaan tradisional mengenai ontologi dan epistemologi, antara lain: apa itu pengetahuan matematika, bagaimana cara memperoleh pengetahuan matematika, apakah basis/landasan bagi pengetahuan matematika, apa yang dikaji filsafat matematika dan bagaimana eksistensi obyek-obyek matematika.

\subsubsection{Aspek Ontologi Filsafat Formalisme}

Obyek-obyek yang dikaji dalam matematika adalah fakta abstrak, konsep, definisi, relasi, operasi abstrak, serta prinsip abstrak. Fakta abstrak berupa konvensi (kesepakatan) yang diungkapkan dengan simbol tertentu, misal simbol 3 menyatakan bilangan bulat positif setelah dua. Konsep adalah ide abstrak yang dapat digunakan untuk menggolongkan atau mengkalisifikasikan sekumpulan obyek, misal segitiga merupakan konsep abstrak sebab sekumpulan benda dapat digolongkan sebagai segitiga atau bukan. Definisi adalah ungkapan yang membatasi suatu konsep. Operasi abstrak dalam matematika adalah suatu fungsi yaitu relasi khusus untuk memperoleh elemen tunggal dari satu atau lebih elemen abstrak yang diketahui Prinsip abstrak adalah hubungan antara berbagai objek dasar matematika.. Prinsip dapat terdiri dari beberapa fakta, beberapa konsep, yang dikaitkan oleh suatu relasi/operasi. Prinsip juga dapat berupa aksioma, teorema, lemma, sifat dll.

Dalam matematika obyek dasar yang dipelajari adalah obyek abstrak, atau berupa obyek mental. Dengan demikian, eksistensi obyek-obyek tersebut hanya ada dalam benak dan mental orang yang memikirkannya, dan tidak pernah dapat dibuat menjadi nyata atau bersifat fisik, serta tidak perlu dihubungkan dengan benda fisik atau diberi makna tertentu. Konsekuensinya, matematika tidak akan pernah menderita nasib menjadi tidak cocok dengan bukti empiris yang baru ditemukan. 


\subsubsection{Aspek Epistemologi Filsafat Formalisme}

Pengetahuan matematika merupakan keyakinan yang terbuktikan atau lebih tepatnya merupakan pengetahuan proposisional yang memuat proposisiproposisi yang diterima, dan tersedia landasan yang cukup untuk melakukan asersi. Matematika adalah pengetahuan a priori, karena memuat proposisi yang diasersi melalui pemikiran, menggunakan logika deduktif dan definisi, konjungsi, aksioma atau postulat metamatika, sebagai dasar untuk memperoleh pengetahuan matematis.

Pendekatan yang lebih luas yang dapat diadopsi secara epistemologi, mendasarkan pada asumsi bahwa pengetahuan dalam matematika dinyatakan dengan sebuah himpunan proposisi, bersama-sama dengan sebuah himpunan prosedur untuk pembuktian proposisi, sehingga tersedia jaminan untuk melakukan asersi. Berdasarkan hal ini, pengetahuan matematika terdiri dari seperangkat himpunan proposisi bersama-sama dengan pembuktiannya. Karena pembuktian matematika didasarkan pada cara berpikir, dan tidak menggunakan fakta-fakta empiris, maka pengetahuan matematika adalah pengetahuan yang bersifat paling pasti dari seluruh pengetahuan yang ada di dunia. Layaklah jika secara agak anarkis matematika menyebut dirinya sebagai dewa pengetahuan yang hanya mau mematuhi aturan yang dibuatnya sendiri.

\subsubsection{Kebenaran Matematis dalam Filsafat Formalisme}

Kebenaran matematika adalah kebenaran menurut definisi atau persyaratan yang menentukan makna dari term-term kunci. Persyaratan ini memberikan ciri khas bahwa validitas kebenaran matematika tidak memerlukan bukti empiris. Kebenaran matematika semata-mata dapat ditunjukkan dengan menganalisis makna yang terkandung dalam term-term di dalamnya, yang di dalam logika disebut sebagai benar secara apriori yang mengindikasikan bahwa nilai kebenarannya bebas secara logis dari atau apriori secara logis pada sebarang bukti eksperimental. 
Sementara itu, proposisi/pernyataan dalam sains empiris, dapat divalidasi secara posteriori, dan terus-menerus terbuka untuk direvisi terhadap bukti baru.

Kebenaran matematika adalah kebenaran yang tidak dapat diganggu gugat, tidak dapat direvisi, mutlak benar dan pasti yang didasarkan pada deduksi murni, yang merupakan satu-satunya metode pembuktian dalam matematika bahwa proposisi-proposisi itu pasti benar asalkan postulat (aksioma) yang mendasarinya itu benar. Jadi proposisi adalah implikasi logis dari postulat-postulat yang digunakan.

Ciri khas kepastian teoritis berakibat pada pernyataan analitis yang tidak membawa informasi faktual, tidak memiliki implikasi faktual, tidak memuat kandungan empiris, sesuatu yang berbeda dengan pernyataan sintetis, sehingga kebenaran pernyataan analitis dapat divalidasi tanpa referensi bukti empiris. Jadi validitas kebenaran matematika tidak terletak pada sifat self-evident-nya dan tidak pula pada dasar empirisnya, akan tetapi diturunkan dari persyaratan yang menentukan makna konsep-konsep matematika. Dengan demikian, proposisi matematika adalah benar menurut definisi, kebenaran a priopri, sekali benar maka untuk seterusnya dan selamanya benar.

Menurut kaum Formalis matematika berasal dari penggunaan pikiran manusia secara bebas, bukan melalui praktek matematisasi dalam kehidupan sehari-hari. Mereka memandang apakah matematika yang dihasilkannya berguna dan dapat diterapkan bukan urusannya. Bagi kaum Formalis, matematika adalah untuk matematika, matematika an sich. Matematika dikembangkan tanpa tujuan untuk dapat digunakan dalam praktek dan atau dapat memberi manfaat nyata.

Jadi kebenaran suatu teorema itu adalah benar secara kondisional, sehingga kebenaran jenis ini berimplikasi pada tidak ada asersi tentang fakta empiris sehingga tidak pernah terjadi pertentangan dengan sebarang penemuan empiris. Konsekuensinya, berbeda dengan hipotesa dan teori pada sains empiris, hipotesa dalam matematika tidak akan pernah menderita nasib menjadi tidak cocock dengan bukti empiris yang baru ditemukan. Tentang hal ini, Einstein memberikan pandangannya (Suriasumantri, 2005), "Sepanjang hukum-hukum matematika mengacu pada realita, hukum-hukum itu tidak pasti; dan sepanjang hukum-hukum itu pasti, mereka tidak mengacu pada realita. 


\subsubsection{Filsafat Formalisme}

Aliran formalisme dalam matematika dapat dilacak pada Bishop Berkeley, tetapi pencetus utamanya adalah David Hilbert (1862-1943), pada tahun 1925, diteruskan oleh J. Von Neumann tahun1931 dan H. Curry tahun 1951. Aliran Formalisme banyak dianut oleh matematikawan Amerika akibat pengaruh Oswald Veblen dan V.E. Huntington. Aliran ini sering disebut aliran postulatsional atau aliran aksiomatik dan dalam pendidikan matematika melahirkan jenis matematika yang disebut matematika modern (New Math) seperti yang sekarang diberikan di sekolah-sekolah.

Formalisme dibentuk dengan tujuan khusus menyingkirkan semua kontradiksi dalam matematika, antara lain mengatasi paradok dalam teori himpunan (Paradok Russel/Paradok Tukang Cukur) dan untuk menyelesaikan tantangan matematika klasik yang disebabkan oleh kritik kaum Intuisionis. Dengan kata lain aliran formalisme bertujuan untuk menterjemahkan seluruh matematika ke dalam sistem formal yang tidak dapat diinterpretasikan (kosong dari arti).

Aliran formalisme menganjurkan pendekatan murni abstrak, berangkat dari prinsip awal, dan mendeduksi segalanya dari prinsip awal tersebut. Karyakarya yang dihasilkannnya sama sekali tidak mempunyai (dan memang tidak perlu mempunyai) hubungan dengan ilmu pengetahuan dan dunia nyata, sesuatu yang sangat membanggakan aliran ini. Menurut aliran formalisme, matematika sekedar rekayasa simbol berdasarkan aturan tertentu untuk menghasilkan sebuah sistem pernyataan tautologis, yang memiliki konsistensi internal, tetapi kosong dari makna. Matematika direduksi hanya menjadi sebuah permainan intelektual, seperti catur. Dalam bahasa populer, formalisme memandang matematika sebagai permainan formal penuh makna yang dimainkan dengan lambang-lambang di atas kertas menggunakan aturan tertentu.

Tesis aliran formalisme ada dua (1) matematika murni dapat diekspresikan dalam bentuk sistem formal yang kosong dari arti, dan di dalamnya mengandung kebenaran matematika yang direpresentasikan dalam bentuk teorema formal, dan 
(2) untuk menunjukkan bahwa sistem formal yang dibangun bebas dari segala macam kontradiksi dan paradok, digunakan alat yang disebut meta-matematika dengan cara mendemonstrasikan bahwa term-termnya bebas dari inkonsisteni.

Secara ringkas, tesis kaum Formalis adalah membangun matematika yang berpusat pada penggunaan sistem lambang formal. Programnya adalah membangun konsistensi seluruh matematika dengan menggunakan teori bukti. Tesisnya bahwa matematika harus dikonstruksi kembali atas dasar kaidah konsistensi dengan lambang-lambang formal, menemukan hasilnya dalam karya Hilbert, Grundlagen der Mathematik.

Kaum formalis memandang matematika sebagai koleksi perkembangan abstrak, dimana term-term matematika semata-mata hanyalah lambang-lambang dan pernyataan adalah rumus-rumus yang melibatkan lambang-lambang tersebut. Dasar untuk aritmatika tidak terletak pada logika tetapi pada koleksi tanda-tanda pralogis atau lambang-lambang dalam seperangkat operasi dengan tanda-tanda ini. Oleh karena itu, menurut aliran Formalisme, matematika kosong dari muatan konkrit dan hanya memuat elemen-elemen lambang ideal, sehingga membangun kekonsistenan dari berbagai cabang matematika menjadi sangat penting. Tanpa disertai bukti kekonsistenan, seluruh penyelidikan matematika tidak berarti sama sekali. Dengan tesis kaum formalis ini, perkembangan matematika aksiomatis terdorong ke puncak kejayaan tertinggi.

Sebagai akhir dari artikel ini, berikut adalah kritik naratif terhadap filsafat formalisme. Melalui konsep kekontinuan, kaum Formalis menerima kehadiran ketakberhinggaan. Persamaan diferensial menyatakan realitas sebagai sebuah kontinum, sehingga perubahan dalam ruang dan waktu dipahami terjadi secara mulus dan tak terputus. Akibatnya tidak tersedia ruang untuk perubahanperubahan yang terjadi secara mendadak. Kontinuitas adalah perubahan yang mulus dan gradual, bertahap dan tidak mendadak. Dalam persamaan diferensial, waktu dianggap terbagi dalam serangkaian time-step yang kecil, sebagai suatu pendekatan terhadap realitas, meskipun kenyataannya tidak ada hal seperti itu dalam realitas, sebab segalanya mengalir, pantharei, demikian Heraklitus. 
Matematika kurang tepat dalam memodelkan realitas yang segalanya mengalir dengan persamaan diferensial, sebab tidak ada peristiwa diskontinu di dalamnya.

Diskontinuitas adalah mendadak, dramatis, dimana perubahan kecil pada sebab dapat mengakibatkan perubahan yang teramat besar pada akibat. Kepak sayap kupu-kupu di Jamaika menimbulkan badai di Antártika. Masa-masa perubahan yang lambat, bertahap, tidak terputus tiba-tiba diselingi oleh belokan yang tajam, patahan kontinuitas, ledakan, bencana, chaos. Peristiwa diskontinu banyak terjadi di alam nyata. Harga minyak tiba-tiba naik sangat tinggi, tetapi tiba-tiba juga turun jatuh bebas. Model matematika yang kontinu tidak menangani masalah yang menyangkut perubahan secara tiba-tiba, sehingga pendekatan matematika terhadap realitas bersifat kasar.

Hasil-hasil perkembangan matematika kontemporer memperlihatkan adanya perkembangan yang sama sekali keluar dari jalur formalisme, meskipun hasil-hasil tersebut disajikan dengan menggunakan logika dalam bentuk sistem aksiomatik milik kaum Formalis. Secara tidak langsung ini memperlihatkan penerimaan kaum Formalis atas perkembangan kontemporer matematika atau mengindikasikan telah terjadinya revisi diam-diam atas fondasi matematika kaum Formalis.

Matematika kontemporer sekarang ini lebih bersahabat dengan aplikasi dan realita keseharian yang begitu mengharubiru dan menghancurleburkan kehidupan manusia, dan matematika berhasil memberikan peringatan dini akan realita tersebut sehingga kematian manusia yang tidak perlu dan kehancuran peradaban dapat diminimalkan. Tsunami, el Nina, el Nino, gempa bumi berkepanjangan, kejatuhan bursa saham, global warming, semuanya adalah gejala-gejala diskontinuitas. Fenomena seperti ini dalam matematika hadir secara nyata dalam chaos dan kompleksitas, perubahan mendadak yang tidak dapat digambarkan oleh rumus matematika klasik, sebuah perubahan yang melibatkan patahan-patahan dalam rangkaian perubahan yang kontinum, suatu bentuk ketakberaturan matematis yang ditemukan dalam dunia nyata. 


\section{Kesimpulan dan Saran}

Sejarah perkembangan matematika menunjukkan bahwa secanggih apapun upaya yang dilakukan untuk membangun matematika yang suci tak ternoda namun tetap saja matematika dilanda krisis dan menghasilkan kontradiksi serta paradok. Berbagai jenis filsafat matematika dengan tesis dan proyeknya masingmasing, telah diciptakan untuk mengatasi krisis, paradok dan kontradiksi. Bagaimanapun juga, pada akhirnya filsafat formalisme adalah yang mampu mendominasi dan merajai perkembangan matematika selama 100 tahun terakhir. Belum lagi keberhasilan salah satu sekte aliran formalisme, Bourbaki Syndicate, dalam mendorong formalisme untuk terus memimpin dan semakin kuat. Namun demikian, ketangguhan formalisme semakin terkurangi sehingga merasa perlu untuk melakukan revisi diam-diam atas fondasi matematika dibangunnya sendiri serta kembali menyatu dengan fenomena sehari-hari, membumi. Keberhasilan Kurt Godel yang mengusung Incompleteness Theorem bahwa ada pernyataan matematika yang kebenarannya ataupun kesalahannya tidak dapat ditunjukkan melalui prosedur sistematik, juga turut menggoyahkan sendi-sendi filsafat formalisme.

Munculnya aliran falibilisme, khususnya dalam pendidikan matematika, juga sebagai reaksi atas formalisme yang terlalu hendak memaksakan pola pikir matematikawan kepada seluruh umat manusia, sehingga matematika harus disajikan secara deduktif. Oleh karena itu, sebagai saran, pembelajaran matematika hendaklah disampaikan dengan lebih memperhatikan keragaman kemampuan dan potensi individu pembelajar, kesadaran bahwa siswa belum sepandai gurunya, mahasiswa S1 dan S2 belum secerdas dosennya, sehingga kesalahan tidak diapresiasi sebagai ekpresi kebodohan tetapi sebagai kesadaran dan keinginan siswa dan mahasiswa untuk tumbuh dan menemukan bakat kreativitasnya, serta mengaitkan pembelajaran matematika sekolah dan perguruan tinggi dengan dunia sehari-hari, induktif dan deduktif, sehingga tidak anti didaktik. 


\section{Daftar Pustaka}

Anglin, W.S., Mathematics: A Concise History and Philosophy, Springer Verlag Inc., 1994.

Boyer, C.B., A History of Mathematics, John Wiley \& Sons, 1968.

Ernest, P., The Philosophy of Mathematics Education, The Palmer Press, 1991.

Eves, H., An Introduction to the History of Mathematics, Holt Rinehart and Watson Inc., 1964.

Gunawan, H., Pidato Pengukuhan Guru Besar ITB, 2007, http://personal.fmipa.itb.ac.id/.../naskah-pidato-ilmiah-gb-itb-hendra-g-v3.pdf, diakses pada 19 Agustus 2010

Sembiring, R.K., Matematika dan Pembelajarannya, Prosiding Seminar Nasional Matematika 2010, Susanto, I. dkk., (eds), UNS, Solo, 2010, 1-12.

Sukardjono, Filsafat dan Sejarah Matematika, Penerbit Universitas Terbuka, 2000 .

Suriasumantri, J.S., Filsafat Ilmu: Sebuah Pengantar Populer, Pustaka Sinar Harapan, 2005.

Woods, A. dan Grant, T., Reason in Revolt : Revolusi Berpikir dalam Ilmu Pengetahuan Modern, IRE Press, 2006. 